\title{
Etiologic diagnosis of bovine infectious abortion by PCR
}

\author{
Diagnóstico etiológico de aborto infeccioso bovino por PCR
}

\begin{abstract}
Teane Milagres Augusto da Silva' ${ }^{\mathrm{I}}$ Raquel Gonzaga de Oliveira ${ }^{\mathrm{I}}$ Juliana Pinto da Silva Mol ${ }^{\mathrm{I}}$ Mariana Noyma Xavier ${ }^{I}$ Tatiane Alves da Paixão ${ }^{I}$ Adriana Cortez ${ }^{\text {III }}$ Marcos Bryan Heinemann ${ }^{\text {II }}$ Leonardo José Richtzenhain ${ }^{\mathrm{III}}$ Andrey Pereira Lage ${ }^{\mathrm{II}}$ Renato de Lima Santos ${ }^{\mathrm{I} *}$
\end{abstract}

\section{ABSTRACT}

Infectious abortion is a significant cause of reproductive failure and economic losses in cattle. The goal of this study was to detect nucleic acids of several infectious agents known to cause abortion including Arcanobacterium pyogenes, Bovine Herpesvirus 1, Brucella abortus, Campylobacter fetus subsp. venerealis, Chlamydophila abortus, Leptospira sp., Listeria monocytogenes, Salmonella sp., Mycoplasma bovis, Mycoplasma bovigenitalium, Neospora caninum, and Tritrichomonas foetus. Tissue homogenates from 42 fetuses and paraffin-embedded tissues from 28 fetuses and 14 placentas/endometrium were included in this study. Brucella abortus was detected in $14.2 \%(12 / 84)$ of the samples. Salmonella sp. DNA was amplified from 2 fetuses, and there was one positive for Neospora caninum, and another for Listeria monocytogenes. This PCR-based approach resulted in identification of the etiology in $19 \%$ of samples, or $20 \%$ if considered fetal tissues only.

Key words: cattle, abortion, Brucella abortus, Salmonella sp., Neospora caninum, Listeria monocytogenes.

\section{RESUMO}

Aborto infeccioso é uma causa significativa de falhas reprodutivas e perdas econômicas na bovinocultura. O objetivo deste estudo foi detectar ácidos nucleicos de vários agentes infecciosos reconhecidos como causadores de aborto, incluindo-se Arcanobacterium pyogenes, Herpesvirus bovino tipo 1, Brucella abortus, Campylobacter fetus subsp. venerealis, Chlamydophila abortus, Leptospira sp., Listeria monocytogenes, Salmonella sp., Mycoplasma bovis, Mycoplasma bovigenitalium, Neospora caninum $e$ Tritrichomonas foetus. Homogenados de tecidos de 42 fetos $e$ tecidos incluídos em parafina de 28 fetos e 14 placentas/ endométrio foram incluídos neste estudo. Brucella abortus foi detectada em 14,2\% (12/84) das amostras. DNA de Salmonella sp. foi amplificado de dois fetos e houve um feto positivo para Neospora caninum e outro para Listeria monocytogenes. Essa metodologia baseada em PCR resultou na identificação da etiologia em $19 \%$ das amostras ou $20 \%$ se considerados somente os tecidos fetais.

Palavras-chave: bovino, aborto, Brucella abortus, Salmonella sp., Neospora caninum, Listeria monocytogenes.

\section{INTRODUCTION}

Abortions have a highly negative impact on reproductive efficiency, resulting in significant economic losses for the cattle industry (DE VRIES, 2006). Under optimal laboratorial conditions, etiologic diagnosis is achieved in 23.3 to $45.5 \%$ of the cases (ANDERSON, 2007). Bovine abortion may be due to infectious, toxic, endocrine, physical or nutritional causes. Infectious agents associated with abortion in cattle include viruses, bacteria, protozoa, and fungus. The exact proportion of cases due to infectious agents is not known, but in $90 \%$ of cases in which an etiologic diagnosis is achieved the cause is infectious (NASCIMENTO \& SANTOS, 2003).

'Departamento de Clínica e Cirurgia Veterinária, Escola de Veterinária (EV), Universidade Federal de Minas Gerais (UFMG). Av. Antônio Carlos, 6627, 31270-901, Belo Horizonte, MG, Brasil. E-mail: rsantos@vet.ufmg.br. *Autor para correspondência. "Departamento de Medicina Veterinária Preventiva, EV, UFMG, Belo Horizonte, MG, Brasil.

IIIDepartamento de Medicina Veterinária Preventiva e Saúde Animal, Faculdade de Medicina Veterinária e Zootecnia (FMVZ), Universidade de São Paulo (USP), São Paulo, SP, Brasil. 
Efficient diagnosis requires a complete diagnostic protocol associated with submission of appropriate specimens and clinical history. Traditional diagnostic tools include serology, histopathology, bacterial and viral isolation, and for certain agents direct examination or immunohistochemistry (ANDERSON, 2007).

Several PCR and RT-PCR (reverse transcription-polymerase chain reaction) protocols have been recently developed for identification of infectious agents in aborted bovine fetuses, including Brucella abortus (LEAL-KLEVEZAS et al., 2000; CORTEZ et al., 2001; RICHTZENHAIN et al., 2002; BRICKER et al., 2003), Leptospira sp. (HEINEMANN et al., 1999; RICHTZENHAIN et al., 2002), Listeria monocytogenes (AZNAR \& ALARCÓN, 2003), Bovine Herpesvirus 1 (KIBENGE et al., 1994; ROCHA et al., 1999), Campylobacter fetus subsp. venerealis (HUM et al., 1997; VARGAS et al., 2003), Neospora caninum (BASZLER etal., 1999; ELLIS etal., 1999; COLLANTESFERNÁNDEZ et al., 2002; PEREIRA-BUENO et al., 2003), Mycoplasma bovis (AYLING et al., 1997; SUBRAMANIAM et al., 1998; HAYMAN \& HIRST, 2003), Mycoplasma bovigenitalium (KOBAYASHI et al., 1998; HIROSE et al., 2001; CARDOSO et al., 2006), Chlamydophila abortus (MADICO et al., 2000; LAROUCAU et al., 2001; DEGRAVES et al., 2003), Salmonella enterica ser. Dublin or Salmonella sp. (KEROUANTON et al., 1996; WHYTE et al., 2002; AMAVISIT et al., 2001), and Arcanobacterium pyogenes (JOST et al., 2002). With the exception of Arcanobaterium pyogenes and Salmonella enterica ser. Dublin, these agents are primarily involved in reproductive diseases in cattle. Although $A$. pyogenes is not a specific cause of abortion, it may cause a suppurative placentitis and abortion (NASCIMENTO \& SANTOS, 2003). Similarly, Salmonella Dublin is usually associated with enteric infection and diarrhea, particularly in calves, although infection of pregnant cows may result in abortion as the only clinical manifestation of infection in the herd (RINGS, 1985). Since the early 1990's, PCR has been increasingly used as a diagnostic tool for etiologic diagnosis of abortion in cattle either as a complement or replacement of time consuming traditional diagnostic methods such as bacterial or viral isolation (ANDERSON, 2007).

Considering the potential of PCR for etiological diagnosis of infectious bovine abortion, the objective of this study was to use several previously established PCR protocols as a comprehensive PCR panel for identification of etiologic agent in tissues from aborted bovine fetuses. This study included frozen tissues as well as formalin-fixed and paraffin-embedded tissues from aborted fetuses and placentas.

\section{MATERIAL AND METHODS}

Samples

Forty-two tissue samples from bovine aborted fetuses $(n=38)$ and stillborn calves $(n=4)$ were collected in several farms located in the States of Minas Gerais ( $\mathrm{n}=11)$, São Paulo ( $\mathrm{n}=26)$, Goiás $(\mathrm{n}=2)$, and Mato Grosso do Sul (n=3), from 1997 to 2004. These samples were homogenates of several fetal tissues pooled together, and were stored at $-20^{\circ} \mathrm{C}$ until DNA extraction.

Formalin-fixed and paraffin-embedded tissue samples from 28 fetuses and 14 placentas and/ or endometrium were obtained from archived tissues originally collected from Minas Gerais $(n=6)$, Bahia $(n=2)$, and São Paulo $(n=1)$, although most of the samples did not have information regarding their origin $(n=33)$. These samples were collected from 1954 to 2004 , and were also used in this study. Five micrometer-thick sections were obtained from all paraffin-embedded tissues and stained with hematoxylin and eosin for histopathological evaluation.

\section{DNA extraction}

DNA extraction from frozen tissues samples was performed using a commercial kit (Wizard Genomic DNA purification Kit, Promega, USA) following the manufacturer's instructions. Briefly, $100 \mu \mathrm{L}$ of thawed homogenates of fetal tissues were mixed with $600 \mu \mathrm{L}$ of Nuclei Lysis Solution and homogenized for 10 seconds. Samples were incubated at $65^{\circ} \mathrm{C}$ for $30 \mathrm{~min}$, followed by addition of $17.5 \mu \mathrm{L}$ proteinase $\mathrm{K}\left(20 \mathrm{mg} \mathrm{mL}^{-1}\right)$ and incubation at $55^{\circ} \mathrm{C}$ for 3 hours, vortexing every hour. Three microliters of RNase A ( $\left.4 \mathrm{mg} \mathrm{mL}^{-1}\right)$ were added, the samples were mixed and incubated at $37^{\circ} \mathrm{C}$ for $30 \mathrm{~min}$. After cooling, $200 \mu \mathrm{L}$ of Protein Precipitation Solution were added, followed by vortexing and centrifugation at $13,000 \mathrm{x}$ g for $4 \mathrm{~min}$. The supernatant was transferred to a new microtube with $600 \mu \mathrm{L}$ of isopropanol, mixed, and centrifuged at $13,000 \mathrm{x}$ g for $3 \mathrm{~min}$. The supernatant was discarded and the pellet was washed with $600 \mu \mathrm{L}$ of $70 \%$ ethanol, followed by a final centrifugation at $13,000 \mathrm{x}$ g for $3 \mathrm{~min}$. Each pellet was dissolved in $100 \mu \mathrm{L}$ of DNA Rehydration Solution by incubating at $65^{\circ} \mathrm{C}$ for 1 hour.

DNA extraction from paraffin embedded tissue sections was performed as previously described (SHI et al., 2004). Briefly, $500 \mu \mathrm{L}$ of $0.1 \mathrm{M} \mathrm{NaOH}$ were added to each microtube containing two $10 \mu \mathrm{m}$-thick tissue sections, and heated at $100^{\circ} \mathrm{C}$ for $20 \mathrm{~min}$. Then, $500 \mu \mathrm{L}$ of phenol:chloroform:isopropanol alcohol (25:24:1) were added, followed by vortexing and centrifugation at $10,000 \mathrm{xg}$ for $10 \mathrm{~min}$. The supernatant was transferred to another microtube and 1 volume of 
chloroform was added, mixed by vortexing and centrifuged at 10,000x $\mathrm{g}$ for $5 \mathrm{~min}$. The upper phase of the supernatant was transferred to another microtube and mixed with 0.1 volumes of $3.0 \mathrm{M}$ sodium acetate, and 1 volume of isopropanol, followed by incubation at $-20^{\circ} \mathrm{C}$ overnight. The suspension of precipitated DNA was then centrifuged at $10,000 \mathrm{x}$ g for $5 \mathrm{~min}$ at $4^{\circ} \mathrm{C}$. The pellet was washed with $75 \%$ ethanol, dried, and diluted in $50 \mu \mathrm{L}$ of distilled water. DNA samples from different tissues of the same fetus were pooled prior to PCR amplification.

DNA quality was assessed by spectrophotometry and PCR amplification of an internal control (a-actin). Samples that did not yield a a-actin amplicon or had DNA concentration lower than 100ng $\mu \mathrm{L}^{-1}$ as assessed by spectrophotometry were excluded from further analysis.

\section{PCR}

DNA samples were PCR tested for detection of 12 infectious agents known to cause abortion in cattle, including Arcanobacterium pyogenes, Bovine Herpesvirus 1, Brucella abortus, Campylobacter fetus subsp. venerealis, Chlamydophila abortus, Leptospira sp., Listeria monocytogenes, Salmonella sp., Mycoplasma bovis, Mycoplasma bovigenitalium, Neospora caninum, and Tritrichomonas foetus. PCR reactions were performed using $13 \mu \mathrm{L}$ of a commercial PCR mix (PCR Supermix, Invitrogen, USA), $0.75 \mu \mathrm{L}$ of a $25 \mu \mathrm{M}$ solution of each primer (Table 1 ), and $1 \mu \mathrm{L}$ of DNA (100 to 500ng per reaction). Amplification of Bovine Herpesvirus 1 sequence was achieved by nested PCR, using $1 \mu \mathrm{L}$ of the product from the first reaction for the second round of amplification. Parameters used were initial denaturation at $95^{\circ} \mathrm{C}$ for $5 \mathrm{~min}$, followed by denaturation at $95^{\circ} \mathrm{C}$ for $1 \mathrm{~min}$, annealing for $1 \mathrm{~min}$, extension at $72^{\circ} \mathrm{C}$ for $1 \mathrm{~min}$ (except in the case of Mycoplasma bovis that had $2 \mathrm{~min}$ extension), and a final extension at $72^{\circ} \mathrm{C}$ for $7 \mathrm{~min}$. The annealing temperatures and number of cycles for each agent are described in table 1 . PCR products were resolved by electrophoresis in a $1 \%$ agarose gel stained with ethidium bromide. Positive controls included DNA from cultured organisms or infected tissues. Positive and negative controls (in which DNA template was replaced by PCR-grade water) were included in all reactions.

\footnotetext{
Statistical analysis

Frequencies of positive results were compared between tissue homogenates and formalinfixed and paraffin-embedded samples by the Fisher's exact text, using Graphpad Instat software, version 3.05 (Graphpad Software, Inc., CA, USA).
}

\section{RESULTS AND DISCUSSION}

The PCR protocols employed in this study efficiently amplified sequences from the positive control samples, without any amplification of negative controls (Figure 1). Results obtained with DNA samples from tissue homogenates from aborted fetuses are described in table 2. Only DNA from Brucella abortus and Listeria monocytogenes were successfully amplified from formalin-fixed and paraffin-embedded tissue samples from aborted fetuses and placentas (Table 2).

Brucella abortus was the most frequent agent identified with an overall frequency of $14.28 \%$ $(12 / 84)$, which was followed by two fetuses that were positive for Salmonella sp., one positive for Neospora caninum, and another positive for Listeria monocytogenes. These results support the notion that B. abortus is the most prevalent cause of infectious abortion in Southeastern and Central Western regions of Brazil, which is in good agreement with a recent PCR-based survey (CORTEZ et al., 2006). Importantly, there was no significant difference in the frequency of positivity for $\boldsymbol{B}$. abortus between tissue homogenates collected from 1997 and 2004, and paraffin-embedded tissues collected from 1954 to 2004 ( $\mathrm{P}<0.05$, Fisher's exact test). Although the present study was not designed to study prevalence of infectious abortion, these results may indicate a relatively high frequency of bovine brucellosis during these two periods of time. Conversely, a recent study in Southern Brazil that included multiple diagnostic assays identified $N$. caninum as the most frequent cause of abortion in cattle (CORBELLINI et al., 2006).

Fetal epicarditis was observed in one of the cases of B. abortus infection, and was characterized by a lymphoplasmacytic and neutrophilic diffuse inflammatory infiltrate with accumulation of fibrin on the epicardium. Experimental infection of pregnant cows is often associated with fibrinous pericarditis (XAVIER et al., 2009), which is in good agreement with the finding of epicarditis in one of the aborted fetuses naturally infected with $\boldsymbol{B}$. abortus in this study. The fetus that was positive for L. monocytogenes had a mild focal lympho-histiocytic endocarditis. Although $\boldsymbol{L}$. monocytogenes can cause inflammatory changes in the heart (SCHLAFER \& MILLER, 2007), in the present case the endocarditis can not be attributed to $\boldsymbol{L}$. monocytogenes with certainty since no organisms were observed in association with the lesion, which is often the case in L. monocytogenes induced lesions. Multifocal miocardial necrosis and fibrosis, associated with centrilobular necrosis and fibrosis due to chronic passive congestion were observed in one of the fetuses.

Ciência Rural, v.39, n.9, dez, 2009. 
Table 1 - Primers sequence and PCR reaction parameters for detection of bovine infectious abortion agents.

\begin{tabular}{|c|c|c|c|c|c|}
\hline Agent / gene & Primers & Annealing $\left({ }^{\circ} \mathrm{C}\right)$ & Cycles & Product (bp) & Reference \\
\hline \multirow[t]{2}{*}{$\begin{array}{l}\text { Arcanobacterium } \\
\text { pyogenes }\end{array}$} & $\begin{array}{l}\text { ggeccgaatgtcaccgc } \\
\text { aactccgectctagcgc }\end{array}$ & 55 & 35 & 270 & JOST et al. (2002) \\
\hline & $\begin{array}{l}\text { tcgaargccgagtacctgcg } \\
\text { ccagtcccaggcraccgtcac }\end{array}$ & 60 & 35 & 468 & \\
\hline Bovine Herpesvirus 1 * & $\begin{array}{l}\text { tggtggccttygaccgcgac } \\
\text { gctccggcgagtagctggtgtg }\end{array}$ & 62 & 35 & 344 & ROS \& BELAK (1999) \\
\hline Brucella abortus & $\begin{array}{l}\text { tggctcggttgccaatatcaa } \\
\text { cgcgcttgcctttcaaggtctg }\end{array}$ & 60 & 40 & 223 & BAILY et al. (1992) \\
\hline $\begin{array}{l}\text { Campylobacter fetus } \\
\text { subsp. venerealis }\end{array}$ & $\begin{array}{l}\text { cttagcagtttgcgatattgccatt } \\
\text { gcttttgagataacaataagagctt }\end{array}$ & 50 & 30 & 142 & HUM et al. (1997) \\
\hline Chlamydophila abortus & $\begin{array}{l}\text { atgaaacatccagtctactgg } \\
\text { ttgtgtagtaatattatcaaa }\end{array}$ & 50 & 30 & 300 & $\begin{array}{l}\text { LAROUCAU et al. } \\
(2001)\end{array}$ \\
\hline Leptospira sp. & $\begin{array}{l}\text { ggcggcgcgtcttaaacatg } \\
\text { ttagaacgaagttacccccett }\end{array}$ & 63 & 29 & 331 & MERIEN et al. (1992) \\
\hline Listeria monocytogenes & $\begin{array}{l}\text { cggaggttccgcaaaagatg } \\
\text { cctccagagtgatcgatgtt }\end{array}$ & 55 & 35 & 234 & $\begin{array}{l}\text { AZNAR \& ALARCÓN } \\
\text { (2003) }\end{array}$ \\
\hline $\begin{array}{l}\text { Mycoplasma } \\
\text { bovigenitalium }\end{array}$ & $\begin{array}{l}\text { ggtagatgccgcatggcatttacgg } \\
\text { cattcaatatagtggcatttcctac }\end{array}$ & 61 & 37 & 312 & $\begin{array}{l}\text { KOBAYASHI et al. } \\
(1998)\end{array}$ \\
\hline Mycoplasma bovis & $\begin{array}{l}\text { ttacgcaagagaatgcttca } \\
\text { taggaaagcaccctattgat }\end{array}$ & 53 & 35 & 1626 & $\begin{array}{l}\text { SUBRAMANIAM et al. } \\
\text { (1998) }\end{array}$ \\
\hline Neospora caninum & $\begin{array}{l}\text { cctcccaatgcgaacgaaa } \\
\text { gggtgaaccgagggagttg }\end{array}$ & 57 & 35 & 275 & BASZLER et al. (1999) \\
\hline Salmonella sp. & $\begin{array}{l}\text { accgctaacgctcgectgtat } \\
\text { agaggtggacgggttgctgccgtt }\end{array}$ & 56 & 35 & 159 & AMAVISIT et al. (2001) \\
\hline Tritrichomonas foetus & $\begin{array}{l}\text { cgggtcttcctatatgagacagaacc } \\
\text { cetgccgttggatcagtttcgttaa }\end{array}$ & 67 & 40 & 347 & $\begin{array}{l}\text { FELLEISEN et al. } \\
(1998)\end{array}$ \\
\hline$\alpha$-actin & $\begin{array}{l}\text { tcaaggagaagctctgctacgtg } \\
\text { ttgccgatggtgatgacctg }\end{array}$ & 60 & 40 & 162 & MÜLLER et al. (2003) \\
\hline
\end{tabular}

* Nested PCR.

A specific etiologic diagnosis in cases of bovine abortion is highly desirable since control measures vary according to the agent involved. The overall rate of successful diagnosis in the present study was $19.04 \%(16 / 84)$, which is a lower rate when compared to protocols that include several different diagnostic tests that usually result in success rates ranging from 23.3 to $45.5 \%$ (ANDERSON, 2007).
Importantly, the success rate obtained in this study is similar to a recent PCR-based study that included four different agents, and resulted in an etiologic diagnosis in $22.6 \%$ of the cases (CORTEZ et al., 2006). The large proportion of negative results observed in this study $(80.95 \%)$ may be attributed to non-infectious abortions, or infectious abortions caused by organisms that were not included in the panel or by abortions caused by 


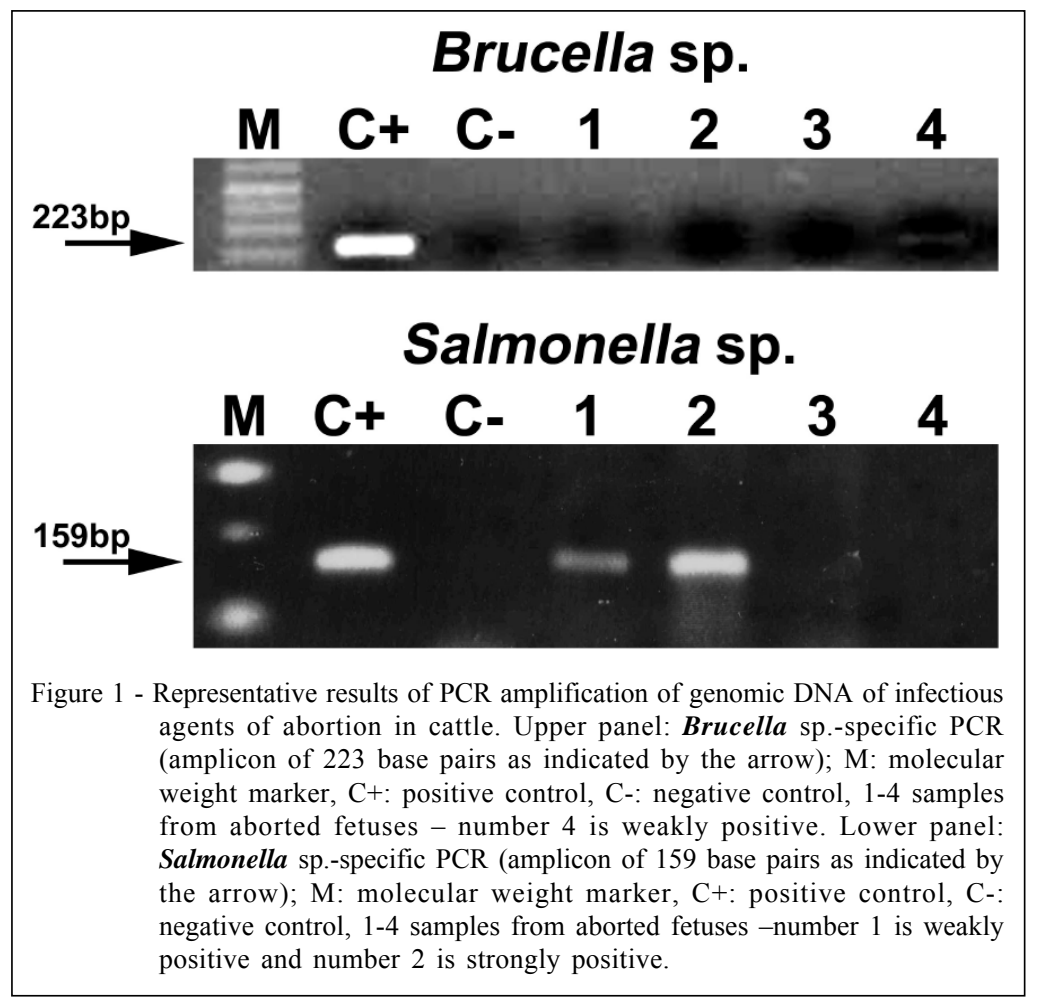

one of the organisms included in the panel, but with concentrations of genomic DNA in the sample that was below the limit of detection of the method. Therefore, these results indicate the potential of PCR as an additional diagnostic tool for identification of infectious agents causing abortion in cattle. Importantly, when several diagnostic approaches are employed together, the rate of success apparently is increased in comparison to PCR alone (ANDERSON, 2007). Each one of the agents may be identified by other specific techniques such as bacteriologic or viral isolation, immunohistochemistry or immunofluorescence, serology, among others (ANDERSON, 2007). However, availability of these methods for all major infectious causes of abortion in cattle requires optimal laboratorial conditions. It is noteworthy that extremely high sensitivity of PCR methods under laboratorial conditions may not be reproducible under field conditions since suboptimal sampling and storage may have a major impact on sensitivity as recently reported for the application of a diagnostic PCR-based method under field conditions in Brazil (PAIXÃO et al., 2008).

Table 2 - PCR results for etiologic diagnosis of abortion in bovine tissue homogenates from aborted fetuses $(\mathrm{n}=42)$ from the states of Minas Gerais, São Paulo, Goiás, and Mato Grosso do Sul; and formalin-fixed and parafin-embedded bovine tissues from aborted fetuses $(\mathrm{n}=28)$ and placentas $(\mathrm{n}=14)^{*}$.

\begin{tabular}{lcccl}
\hline \multirow{2}{*}{ Agent } & & & & \\
& Tissue Homogenates $(\mathrm{n}=42)$ & - & & \\
& & Fetuses $(\mathrm{n}=28)$ & Placenta $(\mathrm{n}=14)$ & Histopathology \\
\hline Brucella abortus & $5(11.9 \%)$ & $5(17.8 \%)$ & $2(14.3 \%)$ & Epicarditis $(1 / 1)$ \\
Salmonella sp. & $2(4.7 \%)$ & $0(0 \%)$ & $0(0 \%)$ & N/A \\
Neospora caninum & $1(2.4 \%)$ & $0(0 \%)$ & $0(0 \%)$ & N/A \\
Listeria monocytogenes & $0(0 \%)$ & $1(3.6 \%)$ & $0(0 \%)$ & Endocarditis $(1 / 1)$ \\
\hline
\end{tabular}

* PCR reactions for detection of Bovine Herpesvirus 1 (nested PCR), Leptospira sp., Campylobacter fetus venerealis, Arcanobacterium pyogenes, Chlamydophila abortus, Mycoplasma bovis, Mycoplasma bovigenitalium, Tritrichomonas foetus, yelded negative results with all samples.

** N/A = not applicable 
Although infectious agents are recognized as the most important cause of abortion in cattle, since $90 \%$ of the cases in which the cause is identified are infectious, abortion in cattle may be due to non infectious causes. These include toxic (e.g. toxic plants such as Tetrapterys multiglandulosa or Ataleia glazioviana), endocrine dysfunction (either endogenous or exogenous/iatrogenic such as administration of prostaglandin $\mathrm{F} 2 \alpha$ or corticosteroids), traumatic (manipulation during diagnosis of pregnancy or placement of intrauterine pipettes), or nutritional deficiency (NASCIMENTO \& SANTOS, 2003).

Although there are several recent reports of development and application of PCR for diagnosis of specific causes of abortion (HUM et al., 1997; KOBAYASHI et al., 1998; SUBRAMANIAM et al., 1998; BASZLER et al., 1999; AMAVISIT et al., 2001; LAROUCAU et al., 2001; JOST et al., 2002; RICHTZENHAIN et al., 2002; AZNAR \& ALARCÓN, 2003), in this study a comprehensive panel of PCR was applied to fetal tissue homogenates stored at $-20^{\circ} \mathrm{C}$ as well as paraffin-embedded tissues with satisfactory results. These data will be useful for developing a fourchannel real time multiplex PCR protocol targeting the most significant causes of abortion in Brazil.

\section{CONCLUSION}

The use of a comprehensive PCR panel including 12 infectious agents associated with abortion in cattle resulted in the establishment of an etiologic diagnosis in $19 \%$ of the cases, which included paraffinembbedded tissues and frozen tissue homogenates. Brucella abortus was the most frequent infections agent identified by this PCR panel.

\section{ACKNOWLEDGEMENTS}

This study was supported by the Fundação de Amparo a Pesquisa do Estado de Minas Gerais (FAPEMIG) - grant CVZ236/ 04 for RLS, and Coordenação de Aperfeiçoamento de Pessoal de Nível Superior (CAPES, Edital Pró-equipamentos 01/2007). MNX, TAP, APL, and RLS are recipients of fellowships from the Conselho Nacional de Desenvolvimento Científico e Tecnológico (CNPq). We are grateful to Maristela V. Cardoso, Marcelo B. Labruna, and Elvio C. Moreira for providing control DNA samples.

\section{REFERENCES}

AMAVISIT, P. et al. Rapid PCR detection of Salmonella in horse faecal samples. Veterinary Microbiology, v.79, p.6374, 2001. Available from: <http://www.sciencedirect.com/ science?_ob=ArticleURL\&_udi=B6TD6-42DX1J3-
$6 \&$ user $=10 \&$ rdoc $=1 \&$ fmt $=\&$ \&orig $=$ search $\&$ _sort $=\mathrm{d} \&$ $\mathrm{doc}$ anchor=\&view $=\mathrm{c} \& \quad$ a c c t $=\mathrm{C} 000050221 \&$ version $=1 \&$ _ur 1 Versio $n=0 \&$ us e r i d $=10 \&$ md5 $=312628701 \mathrm{e} 9787 \mathrm{e} 41 \mathrm{a} 9 \mathrm{fd} 5 \mathrm{e} 8 \mathrm{bad} 45531>$. Accessed: sept. 02, 2009. doi: 10.1016/S0378-1135(00)00340-0.

ANDERSON, M.L. Infectious causes of bovine abortion during mid- to late-gestation. Theriogenology, v.68, p.474-486, 2007. Available from: <http://www.theriojournal.com/article/ S0093-691X(07)00129-X/abstract>. Accessed: sept. 02, 2009. doi: $10.1016 / \mathrm{j}$.theriogenology.2007.04.001

AYLING, R.D. et al. Application of the polymerase chain reaction for the routine identification of Mycoplasma bovis. Veterinary Record, v.141, n.12, p.307-308, 1997.

AZNAR, R.; ALARCÓN, B. PCR detection of Listeria monocytogenes: a study of multiple factors affecting sensitivity. Journal of Applied Microbiology, v.95, p.958-966, 2003. Available from: <http://www3.interscience.wiley.com/journal/ 118896529/abstract $>$. Accessed: sept. 02, 2009. doi: 10.1046/ j.1365-2672.2003.02066.x.

BASZLER, T.V. et al. Detection by PCR of Neospora caninum in fetal tissues from spontaneous bovine abortions. Journal of Clinical Microbiology, v.37, n.12, p.4059-4064, 1999. Available from: <http://jcm.asm.org/cgi/reprint/37/12/4059>. Accessed: sept. 02, 2009.

BAILY, G.G. et al. Detection of Brucella melitensis and Brucella abortus by DNA amplification. Journal of Tropical Medicine and Hygiene, v.95, p.271-275, 1992.

BRICKER, B.J. et al. Evaluation of the Brucella abortus speciesspecific polymerase chain reaction assay, an improved version of the Brucella AMOS polymerase chain reaction assay for cattle. Journal of Veterinary Diagnostic Investigation, v. 15, n.4, p.374-378, 2003. Available from: <http://www.jvdi.org/cgi/ reprint/15/4/374>. Accessed: sept. 02, 2009.

CARDOSO, M.V. et al. Estudo comparative entre técnicas de isolamento e PCR para detecção de Mycoplasma e Ureaplasma diversum em muco prepucial e sêmen in natura de touros de monta natural e central de inseminação artificial. Arquivos do Instituto Biológico, v.73, p.33-40, 2006.

COLLANTES-FERNÁNDEZ, E. et al. Quantitative detection of Neospora caninum in bovine aborted fetuses and experimentally infected mice by real-time PCR. Journal of Clinical Microbiology, v.40, n.4, p.1194-1198, 2002. Available from: <http://jcm.asm.org/cgi/content/full/40/4/ 1194? view $=$ long\&pmid=11923330 $>$. Accessed: sept. 02, 2009. doi: 10.1128/JCM.40.4.1194-1198.2002.

CORBELLINI, L.G. et al. Diagnostic survey of bovine abortion with special reference to Neospora caninum infection: Importance, repeated abortion and concurrent infection in aborted fetuses in Southern Brazil. Veterinary Journal, v.172, p.114120, 2006. Available from: <http://www.sciencedirect.com/ science?_ob=ArticleURL\&_udi=B 6 WXN-4G1 PKNH$5 \&$ user $=10 \&$ rdoc $=1 \&$ fmt $=\&$ orig $=$ search \&_sort $=\mathrm{d} \&$ docancho 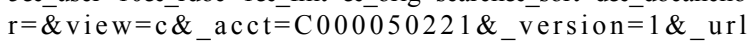 Version $=0 \&$ userid $=10 \& m d 5=916 \mathrm{be} 1 \mathrm{dff} 14 \mathrm{~d} 684 \overline{4} 80 \mathrm{fb} 6482 \mathrm{~b} 7 \mathrm{df} 3 \mathrm{c} \overline{6} \mathrm{~b} 3>$. Accessed: sept. 02, 2009. doi: 10.1016/j.tvj1.2005.03.006.

CORTEZ, A. et al. Detecção de ácidos nucléicos de Brucella spp., Leptospira spp., herpesvirus bovino e virus da diarréia viral

Ciência Rural, v.39, n.9, dez, 2009. 
bovina, em fetos bovinos abortados e em animais mortos no perinatal. Arquivo Brasileiro de Medicina Veterinária e Zootecnia, v.58, n.6, p.1226-1228, 2006. Available from: $<$ http://www.scielo.br/scielo.php?script=sci_arttext\&pid=S0102 $09352006000600036 \& \operatorname{lng}=\mathrm{en} \& \mathrm{nrm}=\mathrm{iso} \& \mathrm{t} \operatorname{lng}=\mathrm{pt}>$. Accessed: sept. 02, 2009. doi: 10.1590/S0102-09352006000600036.

CORTEZ, A. et al. Detection of Brucella DNA from aborted bovine foetuses by polymerase chain reaction. Australian Veterinary Journal, v.79, n.7, p.500-501, 2001.

DEGRAVES, F.J. et al. Quantitative detection of Chlamydia psittaci and $\boldsymbol{C}$. pecorum by high-sensitivity real-time PCR reveals high prevalence of vaginal infection in cattle. Journal of Clinical Microbiology, v.41, n. 4, p.1726-1729, 2003. Available from: <http://jcm.asm.org/cgi/content/full/41/4 1726? view=long\&pmid=12682170>. Accessed: sept. 02, 2009 . doi: $10.1128 /$ JCM.41.4.1726-1729.2003.

DE VRIES, A. Economic value of pregnancy in dairy cattle. Journal of Dairy Science, v.89, n.10, p.3876-3885, 2006. Available from: <http://jds.fass.org/cgi/content/full/89/10/ 3876>. Accessed: sept. 02, 2009.

ELLIS, J.T. et al. Development of a single tube nested polymerase chain reaction assay for the detection of Neospora caninum DNA. International Journal for Parasitology, v.29, p.1589-1596, 1999. Available from: <http://www.sciencedirect.com/ science? ob=ArticleURL \& udi=B6T7F-3Y9HGBR$10 \&$ user $=10 \&$ rdoc $=1 \&$ fint $=\&$ orig $=$ search $\&$ sort $=\mathrm{d} \&$ docanchor $=$ $\&$ view $=c \&$ acct $=\mathrm{C} 000050221 \&$ \& version $=1 \&$ urlVersion $=0$ $\&$ userid $=10 \& \mathrm{md} 5=\mathrm{d} 4 \mathrm{~b} 8731160 \mathrm{c} 434161 \mathrm{~d} 567 \mathrm{ae} 7 \mathrm{da} 177 \mathrm{db} 2>$. Accessed: sept. 02, 2009. doi: 10.1016/S0020-7519(99)00144-7.

FELLEISEN, R.S. et al. Detection of Tritrichomonas foetus by PCR and DNA enzyme immunoassay based on rRNA gene unit sequences. Journal of Clinical Microbiology, v.36, n.2, p.513-519. 1998. Available from: <http://jcm.asm.org/cgi/ content $/$ full/36/2/513?view=long\&pmid $=9466768>$. Accessed sept. 02, 2009.

HAYMAN, B; HIRST, R. Development of a semi-nested PCR for the improved detection of Mycoplasma bovis from bovine milk and mucosal samples. Veterinary Microbiology, v.91, p.91-100, 2003. Available from: <http://www.sciencedirect.com/ science? ob=ArticleURL\& udi=B6TD6-473M9F6$1 \&$ user $=10 \&$ rdoc $=1 \&$ fmt $=\&$ orig $=$ search \& sort $=\mathrm{d} \&$ doca nchor $=\&$ vie $\bar{w}=\mathrm{c} \&$ acct $=\mathrm{C} 000050221 \&$ \& version $=1 \&$ urlVersion $=0 \&$ userid $=10 \& \mathrm{md} 5=21$ cda2442709f7a48d911ea4a90c96e $>$ Accessed: sept. 02, 2009. doi: 10.1016/S0378-1135(02)00305-X.

HEINEMANN, M.B. et al. Detection of Leptospira spp. from pure cultures and from experimentally contaminated bovine semen by polymerase chain reaction. Brazilian Journal of Veterinary Research and Animal Science, v.36, n.1, p.0-0, 1999. Available from: <http://www.scielo.br/scielo.php?script=sci arttext\&pid=S141395961999000100002\&lng=en\&nrm=iso\&tlng $=$ en $>$. Accessed: sept. 02, 2009. doi: 10.1590/S1413-95961999000100002.

HIROSE, K.et al. Detection of Mycoplasma in mastitic milk by PCR analysis and culture method. Journal of Veterinary Medical Science, v.63, n.6, p.691-693, 2001. Available from: $<$ http://www.jstage.jst.go.jp/article/jvms/63/6/63 691/ article/ -char/en>. Accessed: sept. 02, 2009. doi: 10.1292/jvms.63.691.

HUM, S. et al. Evaluation of a PCR assay for identification and differentiation of Campylobacter fetus subspecies. Australian Veterinary Journal, v.75, p.827-831, 1997.
JOST, B.H. et al. Isolation of Arcanobacterium pyogenes from the porcine gastric mucosa. Veterinary Research Communications, v.26, n.6, p.419-425, 2002. Available from: $<$ http://www.springerlink.com/content/t072240750484280/>. Accessed: sept. 02, 2009. doi: 10.1023/A:1020572223059.

KEROUANTON, A. et al. Molecular epidemiological tools for Salmonella Dublin typing. FEMS Immunology and Medical Microbiology, v.14, p.25-29, 1996. Available from: <http:// www3.interscience.wiley.com/journal/119219157/ abstract?CRETRY $=1 \&$ SRETRY $=0>$. Accessed: sept. 02, 2009. doi: 10.1111/j.1574-695X.1996.tb00263.x.

KIBENGE, F.S.B. et al. Amplification of strains of bovine herpesvirus 1 by use of polymerase chain reaction with primers in the thymidine kinase region. American Journal of Veterinary Research, v.55, n.9, p.1206-1211, 1994.

KOBAYASHI, H. et al. In vitro amplification of the 16S rRNA genes from Mycoplasma bovirhinis, Mycoplasma alkalescens, and Mycoplasma bovigenitalium by PCR. Journal of Veterinary Medical Science, v.60, n.12, p.1299-1303, 1998. Available from: $<$ http://www.jstage.jst.go.jp/article/jvms/60/12/ 60_1299/_article/-char/en>. Accessed: sept. 02, 2009. doi: $10.1292 /$ jvms.60.1299.

LAROUCAU, $\mathrm{K}$, et al. Improved sensitivity of PCR for Chlamydophila using pmp genes. Veterinary Microbiology, v.82, p. 155-164, 2001. Available from: <http://www.sciencedirect.com/ science?_ob=ArticleURL\&_udi=B6TD6-439DRMR$\mathrm{K} \&$ user $=10$ \& $\mathrm{rdoc}=1 \&$ fmt $=\&$ orig $=$ search \& sort $=\mathrm{d} \&$ docan chor $=\&$ view $=c$ \& $\_$acct $=C 000050221 \& \_$version $=1 \& \_$urlVersion $=0$ $\&$ userid $=10 \& \mathrm{md} 5=50658 \mathrm{~d} 26 \mathrm{e} 5 \mathrm{e} 09 \mathrm{f} 31 \mathrm{f} 9 \mathrm{f} 91 \mathrm{c} 4 \mathrm{c} 6685 \mathrm{~d} 5 \mathrm{f} 2>$. Accessed: sept. 02, 2009. doi: 10.1016/S0378-1135(01)00381-9.

LEAL-KLEVEZAS, D.S. et al. Use of polymerase chain reaction to detect Brucella abortus biovar 1 in infected goats. Veterinary Microbiology, v.75, n.1, p.91-97, 2000. Available from: $<\mathrm{http}: / / \mathrm{www}$.sciencedirect.com/ science? ob=ArticleURL\&_udi=B6TD6-40J1DVM$9 \&$ user $=10 \&$ rdoc $=1 \&$ fmt $=\&$ orig $=$ search $\&$ sort $=\mathrm{d} \&$ docanchor $=\&$ view $=\mathrm{c} \&$ acct $=\mathrm{C} 000050221 \&$ version $=1 \&$ urlV e r s i o n $=0$ \& u s e r i d $=1-0 \& \mathrm{~m} \mathrm{~d} 5=$ a 22 b773a901e84afab28104cf8d736ea>. Accessed: sept. 02, 2009. doi: 10.1016/S0378-1135(00)00200-5.

MADICO, G. et al. Touchdown enzyme time release-PCR for detection and identification of Chlamydia trachomatis, $\boldsymbol{C}$. pneumoniae, and $\boldsymbol{C}$. psittaci using the $16 \mathrm{~S}$ and $16 \mathrm{~S}-23 \mathrm{~S}$ spacer rRNA genes. Journal of Clinical Microbiology, v.38, n.3, p.1085-1093, 2000. Available from: <http://jcm.asm.org/cgi/ content $/$ full $/ 38 / 3 / 1085$ ? view $=$ long \& pmid $=10699002>$. Accessed: sept. 02, 2009.

MERIEN, F. et al. Polymerase chain reaction for detection of Leptospira spp. in clinical samples. Journal of Clinical Microbiology, v.30, p.2219-2224, 1992. Available from: $<\mathrm{h} \mathrm{t} \mathrm{t} \mathrm{p} \mathrm{://} \mathrm{j} \mathrm{c} \mathrm{m.as} \mathrm{m.org/c} \mathrm{gi/re} \mathrm{print/30/9/}$ 2219? view $=$ long\&pmid=1400983>. Accessed: sept. 02, 2009.

MÜLLER, N. et al. PCR-based detection of canine Leishmania infections in formalin-fixed and paraffin embedded skin biopsies: elaboration of a protocol for quality assessment of the diagnostic amplification reaction. Veterinary Parasitology, v.114, p.223229, 2003. Available from: <http://www.sciencedirect.com/ 
science?_ob=ArticleURL\&_udi=B6TD7-48HXRKR$3 \&$ user $=10 \&$ rdoc $=1 \& \mathrm{fmt}=\&$ orig $=$ search \& sort $=\mathrm{d} \&$ do canchor $=\& v i \bar{e} w=c \&$ acct $=\mathrm{C} 000050221 \&$ version $=1 \&$ u r 1 V e r s i o n $=0 \&$ u s e r i d $=10 \& \mathrm{~m} \mathrm{~d} 5=$ 4fd5f96a6ab00700164d7118 $\overline{\mathrm{e}} 445 \mathrm{eda} 2>$. Accessed: sept. 02, 2009. doi: $10.1016 /$ S0304-4017(03)00139-0.

NASCIMENTO, E.F.; SANTOS, R.L. Patologia da reprodução dos animais domésticos. 2.ed. Rio de Janeiro: Guanabara Koogan, 2003. 137p.

PAIXÃO, T.A. et al. Diagnosis of foot-and mouth disease by real time reverse transcription polymerase chain reaction under field conditions in Brazil. BMC Veterinary Research, v.4, p.53, 2008. Available from: <http://www.biomedcentral.com/ 1746-6148/4/53>. Accessed: sept. 02, 2009. doi: 10.1186/ $1746-6148-4-53$.

PEREIRA-BUENO, J. et al. Evaluation by different diagnostic techniques of bovine abortion associated with Neospora caninum in Spain. Veterinary Parasitology, v.111, p.143152, 2003. Available from: <http://www.sciencedirect.com/ science?_ob=ArticleURL\&_udi=B6TD7-476029R$1 \& \_$user $=10 \&$ rdoc $=1 \&$ fmt $=\&$ orig $=$ search $\&$ sort $=\mathrm{d} \&$ docanchor $=$ $\&$ view $=\mathrm{c} \&$ acct $=\mathrm{C} 000050221 \&$ _version $=1 \&$ urlVersion $=$ $0 \&$ userid $=10 \& \mathrm{md} 5=6 \mathrm{e} 023 \mathrm{ec} 9 \mathrm{cc} 7 \mathrm{cff} 789 \mathrm{dca} 4 \mathrm{a} 1 \mathrm{f} 83 \mathrm{a} 6 \mathrm{daf} 7>$. Accessed: sept. 02, 2009. doi: 10.1016/S03044017(02)00361-8.

RICHTZENHAIN, L.J. et al. A multiplex PCR for the detection of Brucella spp. and Leptospira spp. DNA from aborted bovine fetuses. Veterinary Microbiology, v.87, p.139-147, 2002. Available from: $<\mathrm{ht} \mathrm{t}$ p:// w w w. s c i e n c e d i r e t . c o m/ science?_ob=ArticleURL\&_udi=B6TD6-45KSTXN$1 \& \_$user $=10 \overline{0} \&$ rdoc $=1 \&$ fmt $=\&$ \& orig $=$ search\&_sort $=\mathrm{d} \&$ docancho 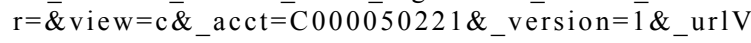 ersion $=0 \&$ userid $=10 \& \mathrm{md} 5=\mathrm{c} 16923 \mathrm{fd} 6054 \mathrm{c} 8 \mathrm{a} 7944 \mathrm{~d} 06 \mathrm{ee} 503 \mathrm{e} 3016>$. Accessed: sept. 02, 2009. doi: 10.1016/S0378-1135(02)00049-4.

RINGS, D.M. Salmonellosis in calves. Veterinary Clinics of North America Food Animal Practice, v.1, p.529-539, 1985.

ROCHA, M.A. et al. Detection of BHV-1 in a naturally infected bovine fetus by a nested PCR assay. Veterinary Research Communications, v.23, n.2, p.133-141, 1999. Available from: <http://www.springerlink.com/content/ 15171104328m6326/>. Accessed: sept. 02, 2009 . doi: $10.1023 / \mathrm{A}: 1006210619910$.

ROS, C., BELAK, S. Studies of genetic relationships between bovine, caprine, cervine, and rangiferine alphaherpesviruses and improved molecular methods for virus detection and identification. Journal of Clinical Microbiology, v.37, n.5, p. $1247-1253,1999$. Available from: < http://jcm.asm.org/cgi/ content $/$ full/37/5/1247? view=long \&pmid=10203465>. Accessed: sept. 02, 2009.

SCHLAFER, D.H.; MILLER, R.B. Female genital system. In: Jubb, Kennedy, and Palmer's pathology of domestic animals. 4.ed. Philadelphia: Elsevier Saunders, 2007. V.3, p. $429-564$.

SHI, S.R. et al. DNA extraction from archival formalin-fixed, paraffin-embedded tissues: heat-induced retrieval in alkaline solution. Histochemistry and Cell Biology, v.122, p.211218, 2004. Available from: <http://www.springerlink.com/ content/8bb30j42qytmlb8m/>. Accessed: sept. 02, 2009. doi: 10.1007/s00418-004-0693-x.

SUBRAMANIAM, S. et al. Species identification of Mycoplasma bovis and Mycoplasma agalactiae based on the uvrC genes by PCR. Molecular and Cellular Probes, v.12, p.161-169, 1998. Available from: $<\mathrm{http} /$ /www.sciencedirect.com/science?_ob=ArticleURL\&_udi=B6WNC45 JB0G9-6\&_user $=10 \&$ rdoc $=1 \&$ fmt $=\&$ orig $=$ search $\&$ sort $=\mathrm{d} \&$ do $\mathrm{c}$ an chor $=\&$ vi e w $=\mathrm{c} \&$ _a c c t $=\overline{\mathrm{C}} 00000502 \overline{2} 1 \&$ \&_ver s i o $n=1 \&$ u r l Ver s i o n $=0 \&$ _ s e r i d $=10 \&$ m $\mathrm{d} 5=6 \mathrm{e} 02 \mathrm{~d} 6 \mathrm{bb} 6 \mathrm{ff} 4 \mathrm{ce} 14 \mathrm{c} 566 \mathrm{ff} 6 \mathrm{~d} 95 \mathrm{e} 75 \mathrm{~b} 04>$. Accessed: sept. 02, 2009. doi: $10.1006 /$ mcpr.1998.0160.

VARGAS, A.C. et al. Phenotypic and molecular characterization of bovine Campylobacter fetus strains isolated in Brazil. Veterinary Microbiology, v.93, p.121-132, 2003. Available from: <http:// www.sciencedirect.com/science?_ob=ArticleURL\&_udi=B6TD6481FSS6-1\& user $=10 \&$ rdoc $=1 \&$ fmt $=\&$ orig $=$ search $\&$ sort $=\mathrm{d} \&$ _docanchor $=\&$ view $=$ c\&_acct $=\mathrm{C} 000050221 \&$ _version $=$ $1 \&_{-}$u r l V e r s i o n $=0 \&$ _ u s e r i d $=10$ \& m d 5 $=$ aae $18683 \mathrm{c} 8 \mathrm{dbc} 2 \mathrm{~d} 70 \mathrm{dfb} 739 \mathrm{f} 3916 \mathrm{eb} 58>$. Accessed: sept. 02, 2009. doi: $10.1016 / \mathrm{S} 0378-1135(03) 00018-\mathrm{X}$.

WHYTE, O. et al. The prevalence and PCR detection of Salmonella contamination in raw poultry. Veterinary Microbiology, v.89, p.53-60, 2002. Available from: <http:// www.sciencedirect.com/science? ob=ArticleURL\&_udi=B6TD646FXS9R-1\&_user $=10 \&$ rdoc $=1 \&$ fmt $=$ \&_orig $=-$ search $\&$ sort $=$ $\mathrm{d} \&$ _docanchor $=\& \mathrm{view}=\mathrm{c} \&$ _acct $=\mathrm{C} 000050221 \&$ \&ersion $=1 \&$ u r l Vers i o n $=\overline{0} \&$ u s e r i d $=10 \&$ m d 5 $=479 \mathrm{~d} 9 \overline{\mathrm{b}} 0122 \mathrm{a} 84 \mathrm{bd} 70 \mathrm{e} 14 \mathrm{ba} 893 \mathrm{ec} 3 \mathrm{~d} 54 \mathrm{a}>$. Accessed: sept. 02, 2009. doi: 10.1016/S0378-1135(02)00160-8.

XAVIER, M.N. et al. Pathology, immunohistochemistry, and bacteriology of tissues and milk of cows and fetuses experimentally infected with Brucella abortus. Journal of Comparative Pathology, v.140, n.3-4, p.147-157, 2009. Available from: <http:/ /www.sciencedirect.com/science?_ob=ArticleURL\&_udi=B6WHW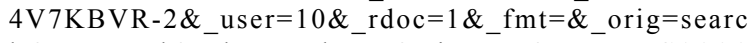 $\mathrm{h} \&$ \& sort $=\mathrm{d} \&$ _docanchor $=\& \mathrm{view}=\mathrm{c} \&$ _acct $=\mathrm{C} 0000$ $50221 \&$ \&ersion $=1 \&$ \&urlVersion $=0 \&$ \& userid $=10 \&$ $\mathrm{md} 5=\mathrm{d} 89 \mathrm{a} 0871173 \mathrm{ccfd} 6 \mathrm{fe} 80 \mathrm{c} 7256648 \mathrm{~d} 5 \mathrm{a} 5>$. Accessed: sept. 02, 2009. doi: $10.1016 /$ j.jcpa.2008.10.004. 